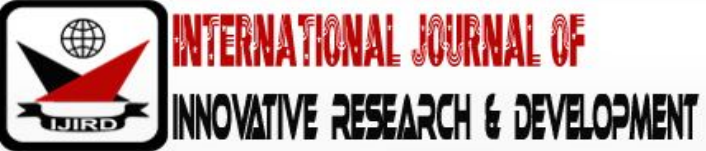

ISSN 2278 - 0211 (Online)

\section{Some Aspects of Limnology and Plankton Population of River Ochekwu, Benue State, Nigeria}

\author{
Oloche Joshua Andrew \\ Student, Department of Fisheries and Aquaculture, Federal University of Agriculture, Makurdi, Nigeria \\ Olufeagba Samuel \\ Associate Professor, Department of Fisheries and Aquaculture, \\ Federal University of Agriculture, Makurdi, Nigeria \\ Omeji Samuel \\ Lecture, Department of Fisheries and Aquaculture, Federal University of Agriculture, Makurdi, Nigeria
}

\begin{abstract}
:
This study examined some aspects of water quality parameters and plankton population of River Ochekwu, Benue State, Nigeria for management purpose. The physico-chemical status of water samples from three stations was investigated monthly for a period of one year. Water temperature, $\mathrm{pH}$, Conductivity, Total Dissolved Solids, and Dissolved Oxygen (DO) were measured in situ with the aid of Hanna Model HI 98129 while BOD was determine using DO meter model DO-5509, Transparency was measured with Secchi Disc and Air temperature was measured with the aid of a Mercury in glass Thermometer. Total Hardness, Total Alkalinity, and Carbon Dioxide were determined titrimetrically. Planktons were

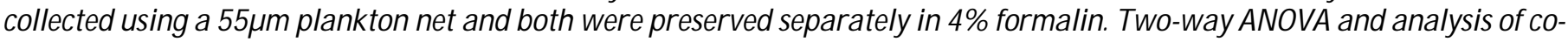
variance at $\mathrm{P} \varangle 0.05$ were used to analyze the result using GLM procedures of the analysis system (SAS). The results showed Air temperature range from $29.23^{\circ} \mathrm{C}$ to $29.98^{\circ} \mathrm{C}$, Water temperature of $26.57^{\circ} \mathrm{C}$ to $26.66^{\circ} \mathrm{C}$, Dissolved Oxygen of $4.59 \mathrm{mg} /$ to $5.98 \mathrm{mg} / \mathrm{l}$, BOD of $2.76 \mathrm{mg} / \mathrm{l}$ to $3.80 \mathrm{mg} / \mathrm{l}, \mathrm{pH}$ of 6.79 to 7.08 , TDS of $77.06 \mathrm{mg} / \mathrm{l}$ to $79.20 \mathrm{mg} / \mathrm{l}$, Transparency of 42.99 to $99 \mathrm{mg} / \mathrm{l}$, EC of $80.25 \mu \mathrm{S} / \mathrm{cm}$ to $83.56 \mu \mathrm{S} / \mathrm{cm}$, Total Alkalinity of $49.87 \mathrm{mg} / \mathrm{l}$ to $51.40 \mathrm{mg} / \mathrm{l}$, Total Hardness of $37.14 \mathrm{mg} / \mathrm{l}$ to $46.05 \mathrm{mg} / \mathrm{l}$, and Carbon dioxide of $42.65 \mathrm{mg} / \mathrm{l}$ to $46.24 \mathrm{mg} / \mathrm{l}$. Thirty three species of phytoplankton from four families were identified with Chlorophyceace dominating with 18 species followed by Cyanophyceace with 7 species, Bacillariophyceace with 6 species and Chrysophyceace with 4 species. Zooplankton composed of 23 species from three families with 12 species of Rotifera, 6 species of Cladocera and 5 species of Copepoda. The results obtained fell within the maximum permissible limit set by World Health Organization for drinking water. Variations were observed in the parameters by season and stations with plankton being abundant in the wet season.
\end{abstract}

Keywords: River Ochekwu, water quality, plankton, fish

\section{Introduction}

The availability of good quality water is an indispensible feature for preventing diseases and improving quality of life (Oluduro and Aderiye, 2007). Natural water contains some types of impurities whose nature and amount varies (Adefemi and Awokunmi, 2010). Assessment of water is not only for suitability for human consumption but also in relation to its agricultural, industrial, recreational, commercial uses and its ability to sustain aquatic life (Taiwo et al., 2012). The influence of physico-chemical parameters on plankton distribution on Kwa River was studied by (Ebigwai et al., 2014). Water quality affects the abundance, species composition, diversity, stability, and productivity condition of indigenous population of aquatic organisms (Ekweozor and Moslen, 2016). Planktons are very important as they serve as biological indicators where their presence, absence, diversity, abundance and distribution are used to determine the nutrient status or quality of an aquatic environment (Reynold, 2006). Presently, no work has been published on River Ochekwu, Benue State, Nigeria. The aim and objective of this study is to investigate some aspects of limnology and plankton population of River Ochekwu and hence produce a checklist on the biological richness of the river.

\section{Materials and Methods}

Description of the study area: River Ochekwu is located in Apa Local Government area of Benue State. It lies between latitude 70 38 '5.07" N and 70 37' 21.67" North and longitude 70 52 '36.34" E and 70 49' 32.23" East. River Ochekwu is a perennial river with minimal flow during the dry season. It has its source from a mountain in Ankpa in the present day Kogi State. It flows northward from Ankpa to Apa through to Agatu where it flows into River Benue. River Ochekwu serve as the water source to all the settlement along its course. The dense vegetation along the river consist of trees, climbers, shrubs and grasses. 


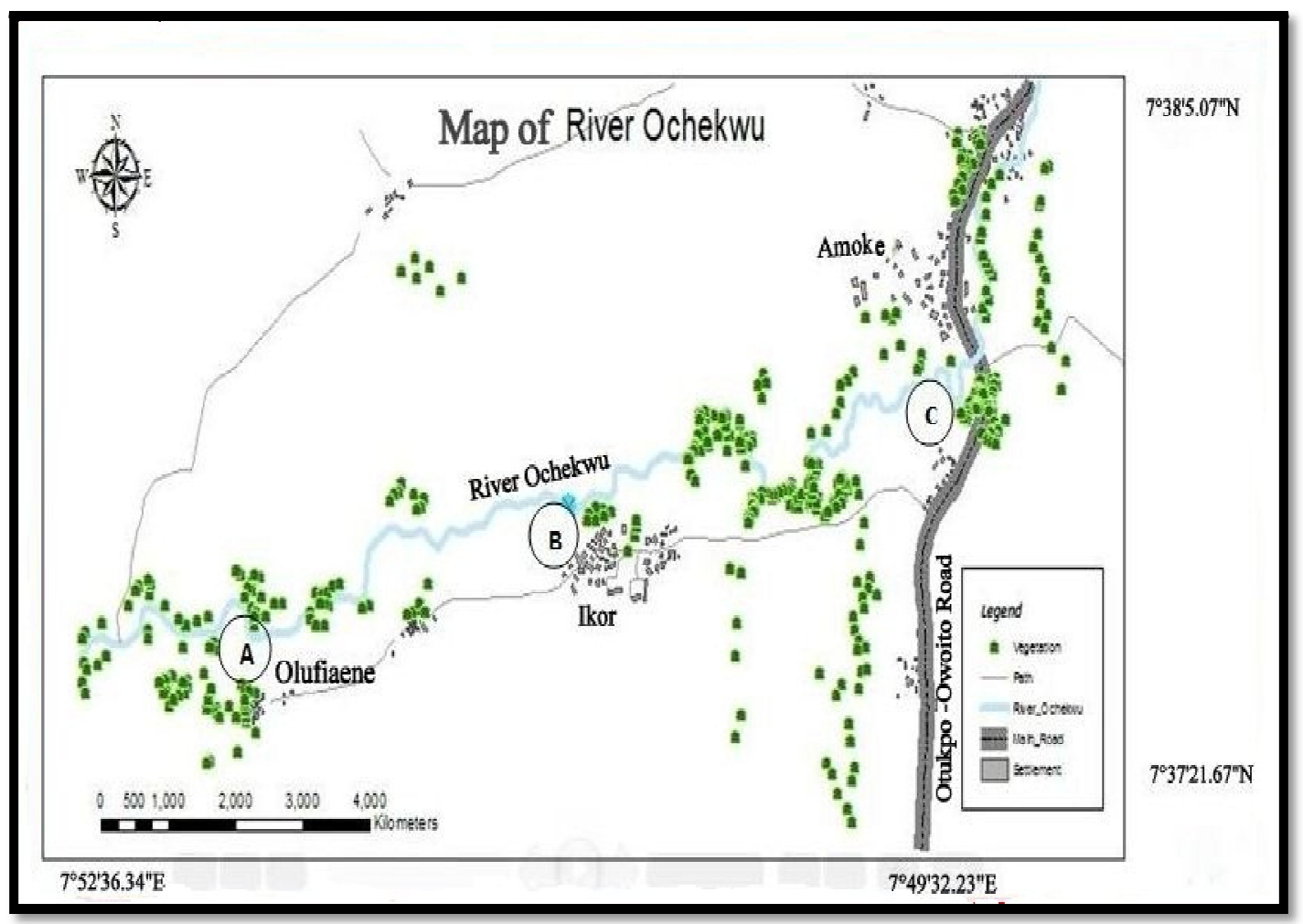

Figure 1: Map of River Ochekwu Showing Sampling Stations

Source: Federal Ministry of Lands and Survey, Makurdi, Benue State

\subsection{Sampling Stations}

Three (3) sampling stations were identified on the river and named as A, B and C. The stations were, A (Olufiaene), B (Ikor) and C (Amoke). The distance from station A to B is $2.68 \mathrm{~km}$ while from station B to C is $2.67 \mathrm{~km}$. The sites were selected at strategic point and easily accessible locations based on the presumption that there was measurable problem at that location along the river. On the three sites selected, the water quality, and plankton abundance were assessed monthly.

\subsection{Sampling Procedure}

The study was carried out for a period of twelve (12) months from June, 2016 to May, 2017. Water samples were collected in triplicate fortnightly over a period of twelve (12) months cutting across rainy and dry seasons. A total of nine plastic bottles of 150cl, three each for every sampling station were properly washed and rinse and labeled. Water samples were collected in each bottle by dipping the bottle $10 \mathrm{~cm}$ below the water level at designated sampling stations and brought to the laboratory at the Department of Fisheries and Aquaculture, Federal University of Agriculture Makurdi for the determination Carbon dioxide, Alkalinity and Hardness titrimatically. Transparency was determined with the aid of a standard Secchi disc. Reagent bottles of $250 \mathrm{ml}$ were used to collect water samples at each site at the designated sampling stations and incubated for five (5) days in an enclose chamber for BOD determination. Water physico-chemical parameters such as, Temperature, TDS, pH, EC and DO where all measured in situ with the aid of the Hanna portable pH/EC/TDS/ TEMPERATURE waterproof test kit, model: HI 98129. The DO was measured using DO meter while air temperature was measured using the mercury in glass thermometer. Phyplankton and zooplankton were sampled by means of plankton net, preserved with $4 \%$ formalin and taken to the laboratory for identification.

\section{Results}

\subsection{Trends and Changes in the Physico-Chemical Water Parameter of River Ochekwu}

The monthly mean variation and changes in the water physico-chemical parameters of River Ochekwu are presented in figures $2,3,4,5,6,7,8,9,10,11$ and 12 below. Air temperature of the three stations shows that the highest air temperature of 29.98 was recorded in the month of March, 2017 while the lowest air temperature of 29.23 was recorded in the month of January, 2017. The Water Temperature shows that the water temperature level was lowest 26.57 in January 2017, at station C during dry season and was highest 26.66 in dry season at station B in the month of March, 2017. Dissolve Oxygen level Shows that the DO level was at the lowest point 4.59mg/l in March of 2017, at station C during dry season and was at its peak $5.90 \mathrm{mg} / \mathrm{l}$ in the wet season at station A in the month of June, 2016. The monthly mean variations of potential hydrogen $\mathrm{pH}$ level in River Ochekwu Shows that the $\mathrm{pH}$ level was lowest 6.79 in August of 2016, at station A during wet season and was at its peak 7.08 in the dry season at station B in the month of January, 2017. Generally, the pH fluctuates within 6 - 7 throughout the experimental period, from June, 2016 to May, 2017. The Biochemical Oxygen Demand shows that the BOD level was lowest $2.76 \mathrm{mg} / \mathrm{l}$ in the May of 2017, at station B during wet 
season and was highest $3.80 \mathrm{mg} / \mathrm{l}$ in the wet season at station $\mathrm{C}$ in the month of August, 2016. The Electrical Conductivity of River Ochekwu Shows the lowest EClevel of $80.25 \mu \mathrm{s} / \mathrm{cm}$ in the February of 2017, at station B during dry season but was highest $83.56 \mu \mathrm{s} / \mathrm{cm}$ in the wet season at station B in the month of June 2016. The monthly mean variations in Transparency shows it was lowest $42.99 \mathrm{mg} / \mathrm{l}$ in the month of June 2016 at station A during raining season but increases in dry season and highest $44.72 \mathrm{mg} / \mathrm{l}$ in station B in the month of March 2017. River Ochekwu had a Carbon dioxide level of $46.24 \mathrm{mg} / \mathrm{l}$ the highest recorded during the experimental period at station A in the month of November, 2017 with $42.65 \mathrm{mg} / \mathrm{l}$ being the lowest as recorded in state A in the month of November 2017. Total Hardness was lowest in the month of March, 2017 at station B during dry season but had but was highest at station A in wet season in month of October, 2017. It was observed the total hardness in the three stations ranges between $37.14 \mathrm{mg} / \mathrm{l}$ to $46.05 \mathrm{mg} / \mathrm{l}$. Total Dissolved Solid as recorded from River Ochekwu had $50.06 \mathrm{mg} / \mathrm{l}$ to be the lowest value at station A in May 2017 while, the highest value $120.00 \mathrm{mg} / \mathrm{l}$ was recorded at station C in the month of July, 2016. Finally, Alkalinity was lowest $30.82 \mathrm{mg} / \mathrm{l}$ at station $\mathrm{C}$ in the month of September, 2016 during the wet season but was highest $51.40 \mathrm{mg} / \mathrm{l}$ in station C in November 2016 during the dry season.

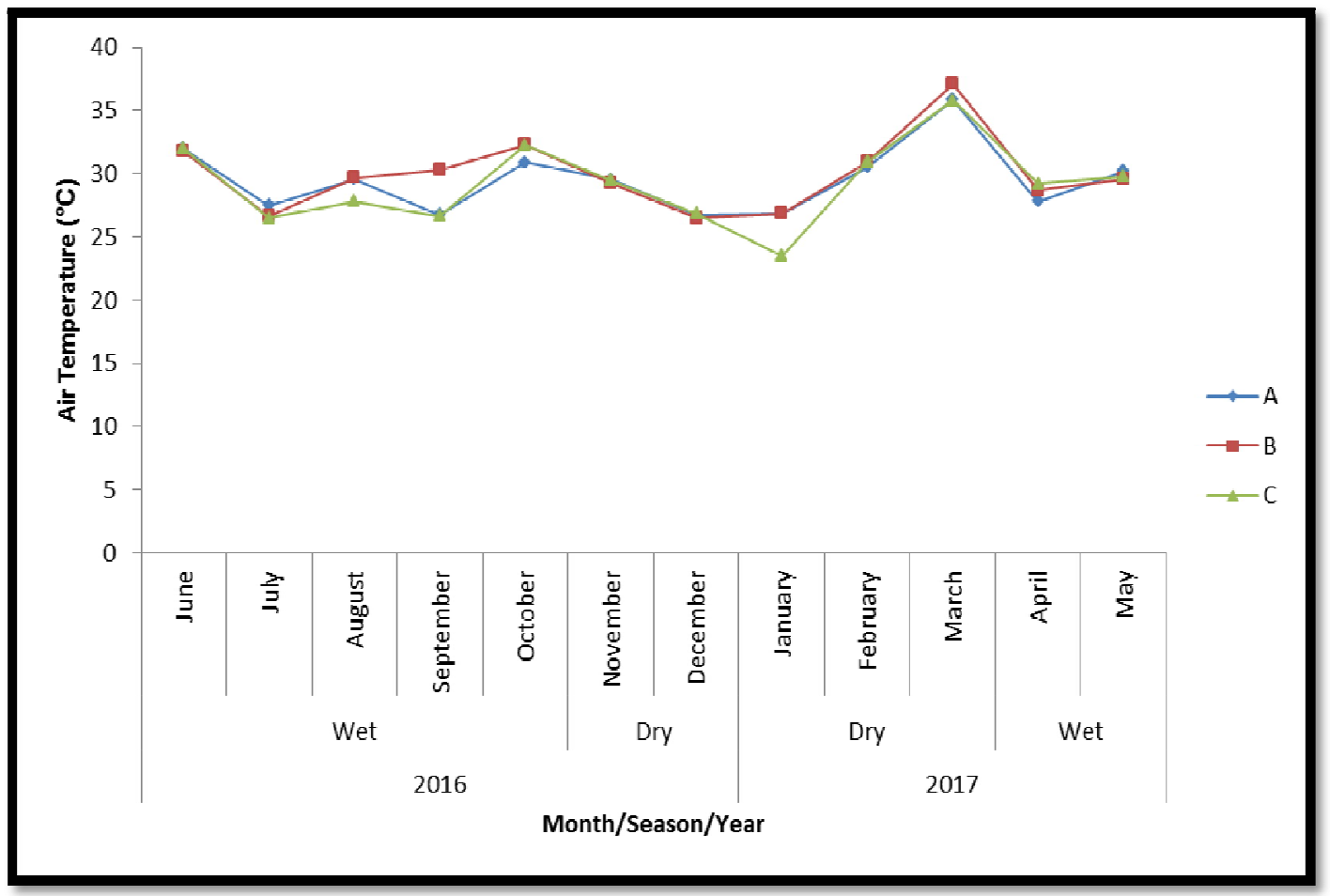

Figure 2: Monthly variation in air temperature of River Ochekwu

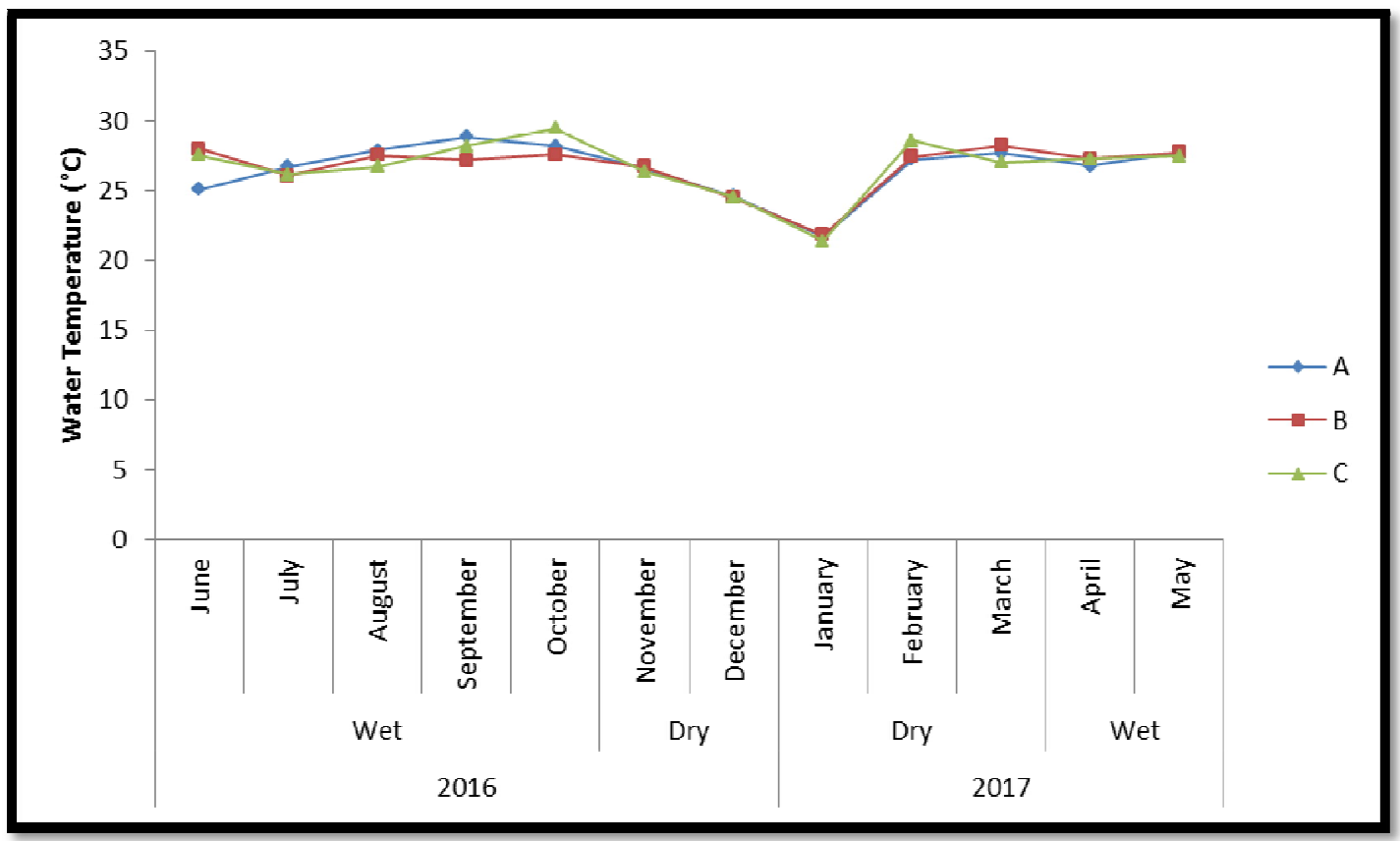

Figure 3: Monthly Variation in Water Temperature of River Ochekwu 


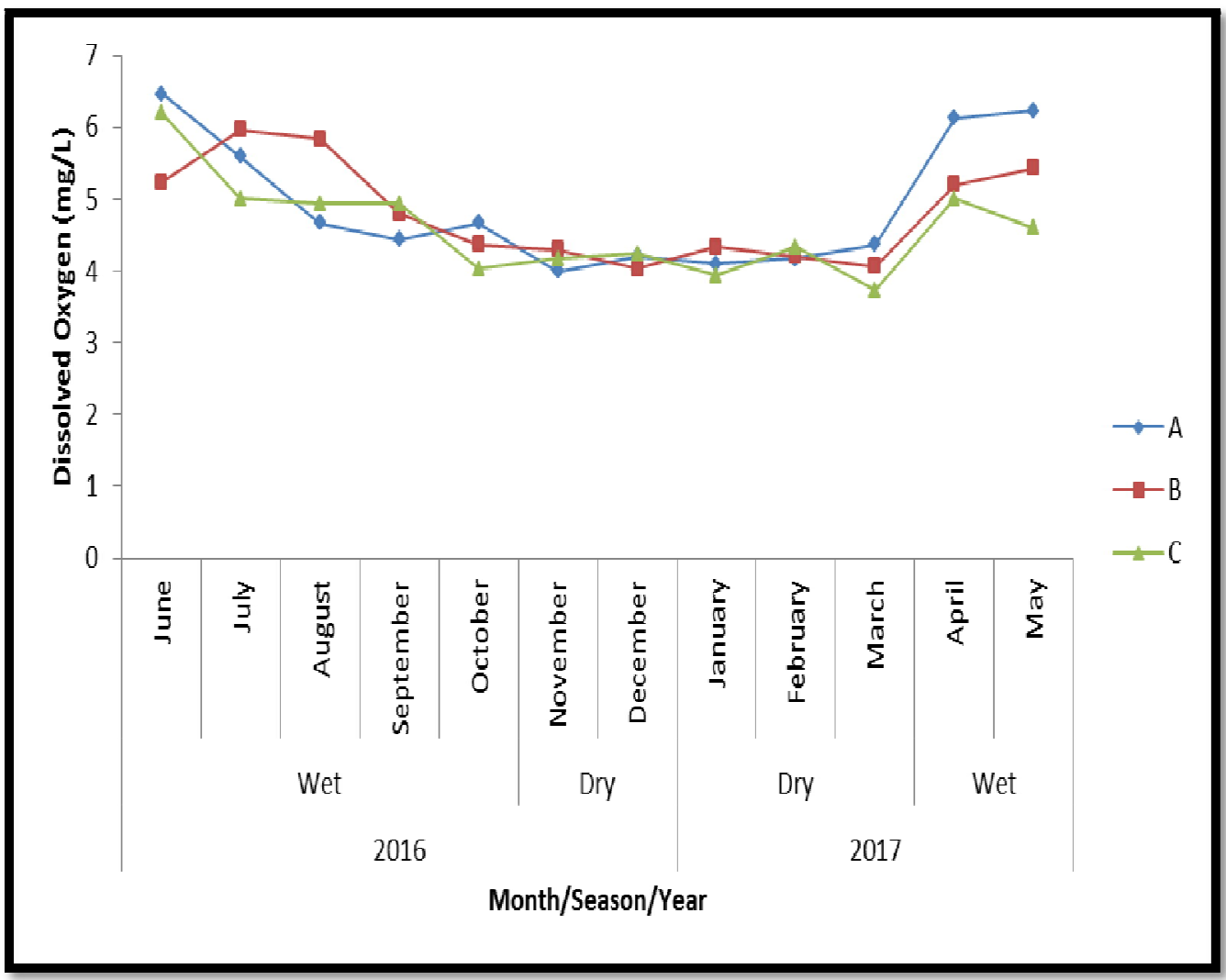

Figure 4: Monthly Variation Dissolves Oxygen Level of River Ochekwuu

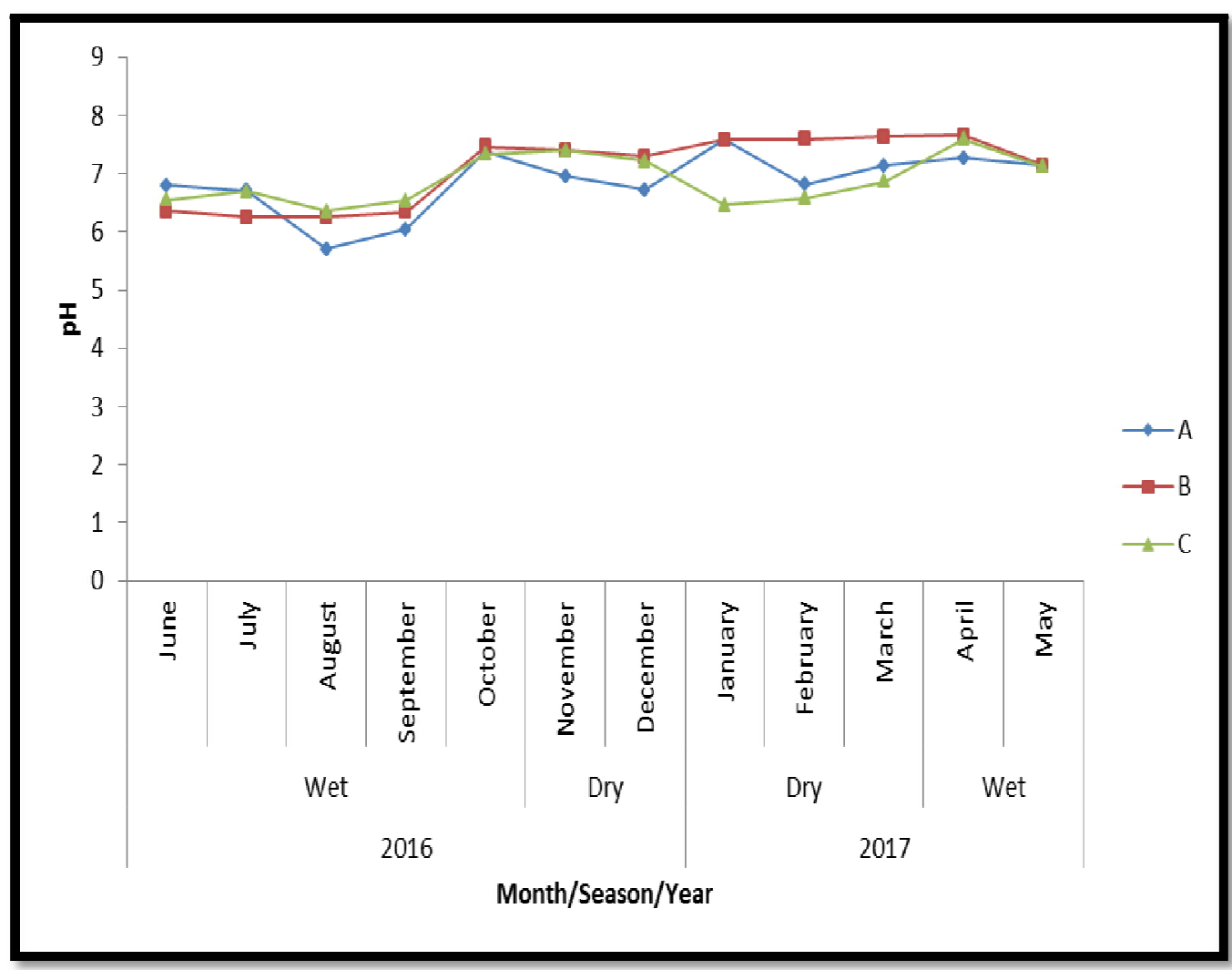

Figure 5: Monthly variation in $\mathrm{pH}$ level of River Ochekwu 


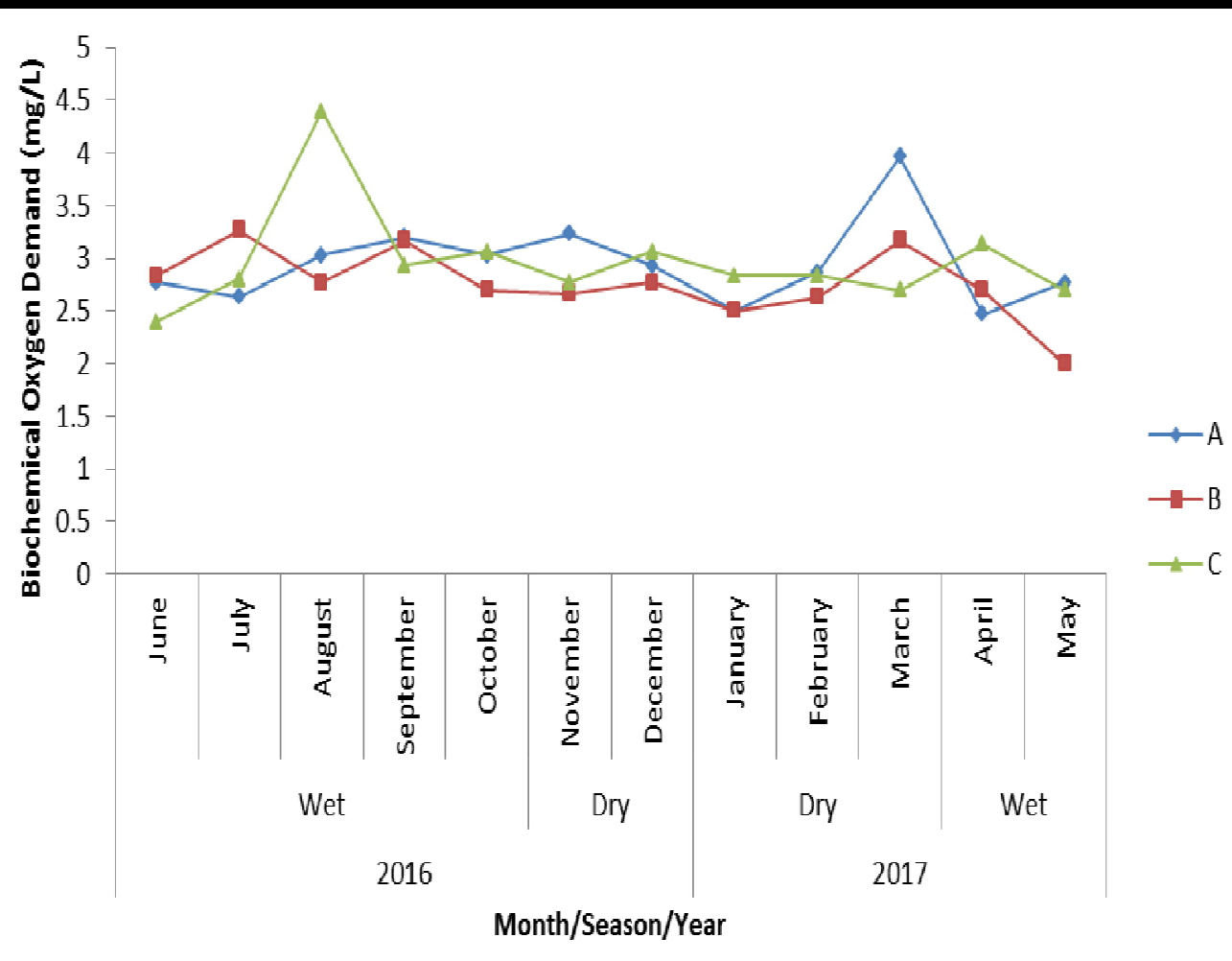

Figure 6: Monthly Variation in Biochemical Oxygen Demand Level of River Ochekwu

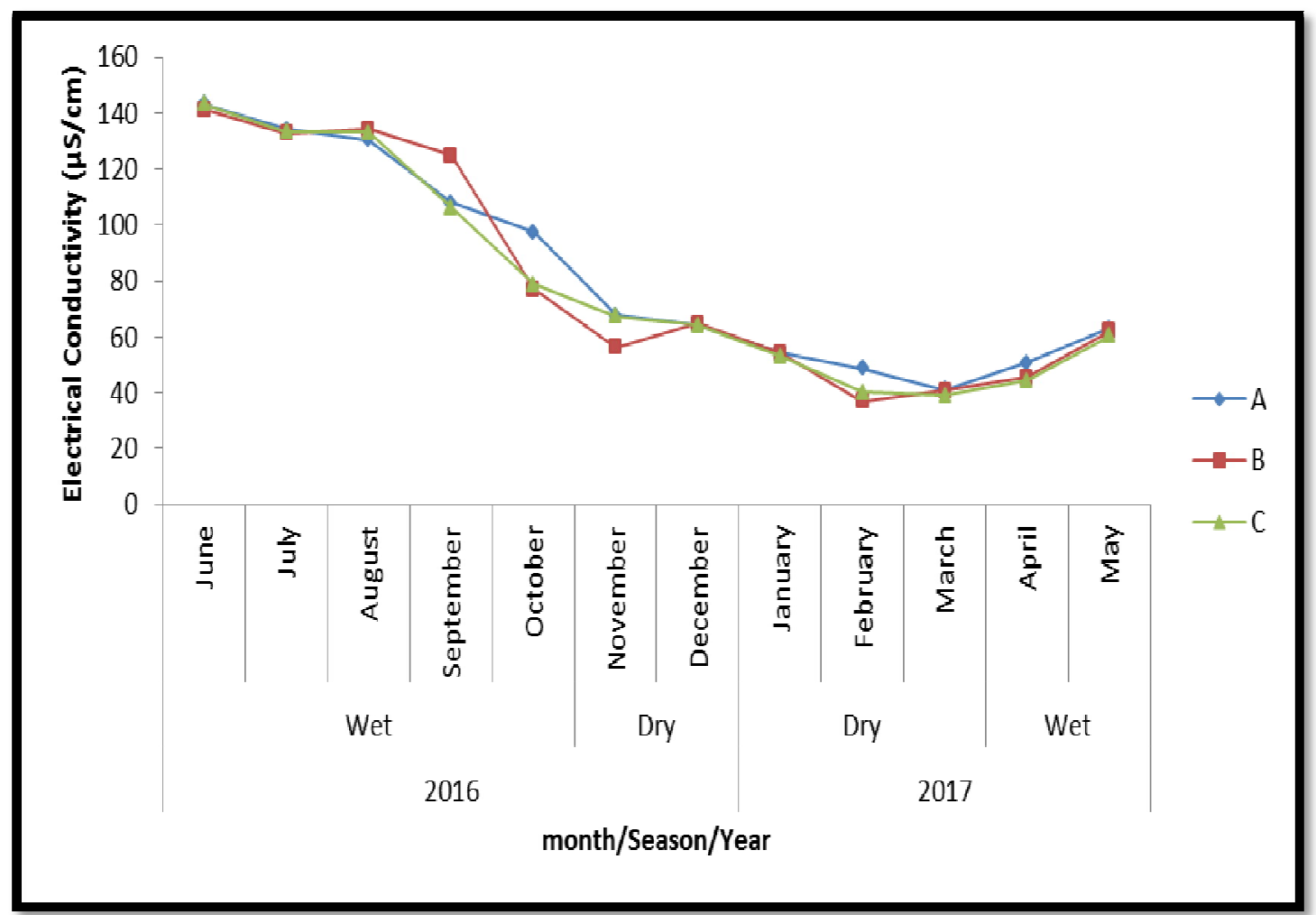

Figure 7: Monthly Variation of Electrical Conductivity Level of River Ochekwu 


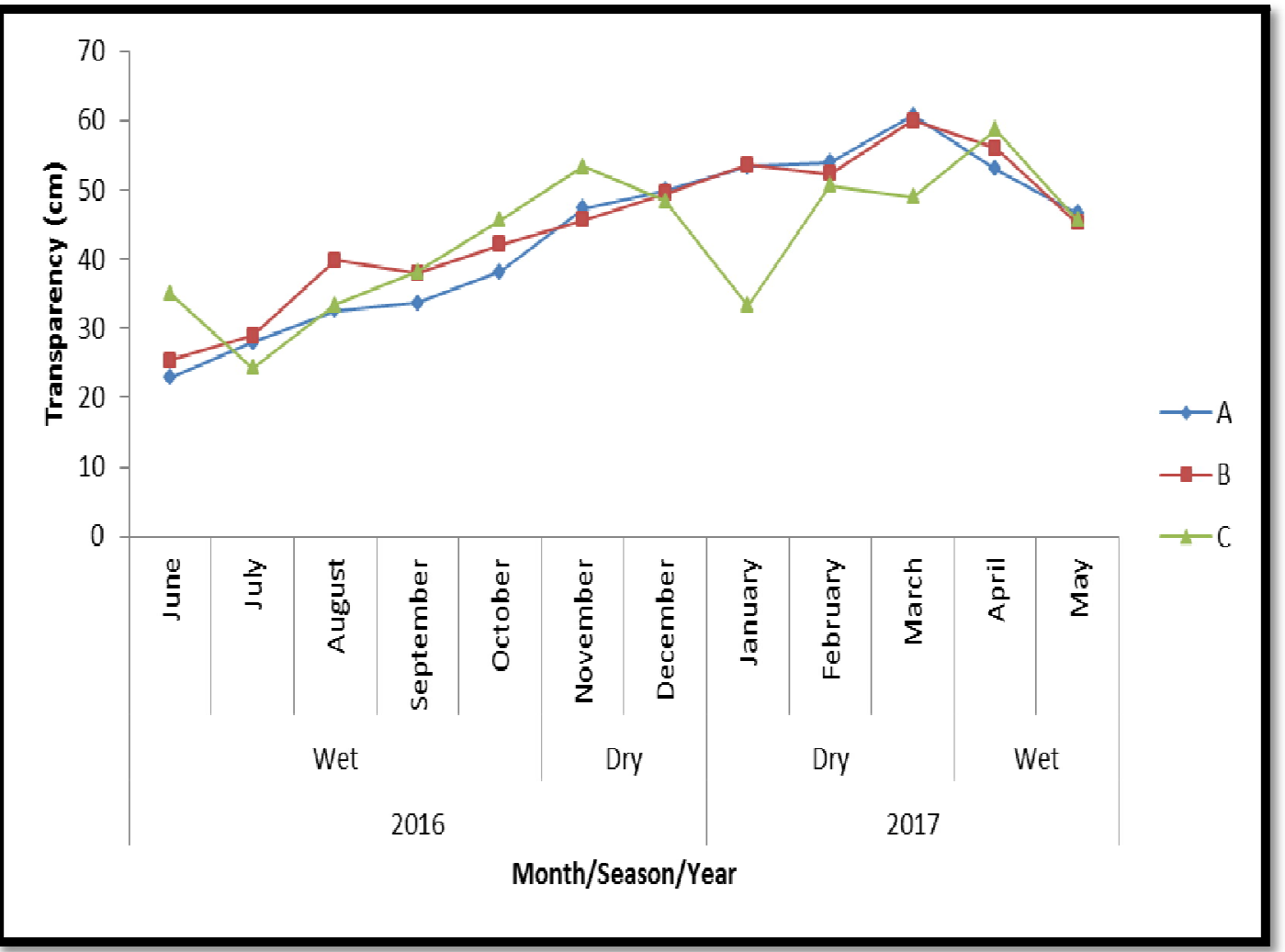

Figure 8: Monthly Variation in Transparency Level of River Ochekwu

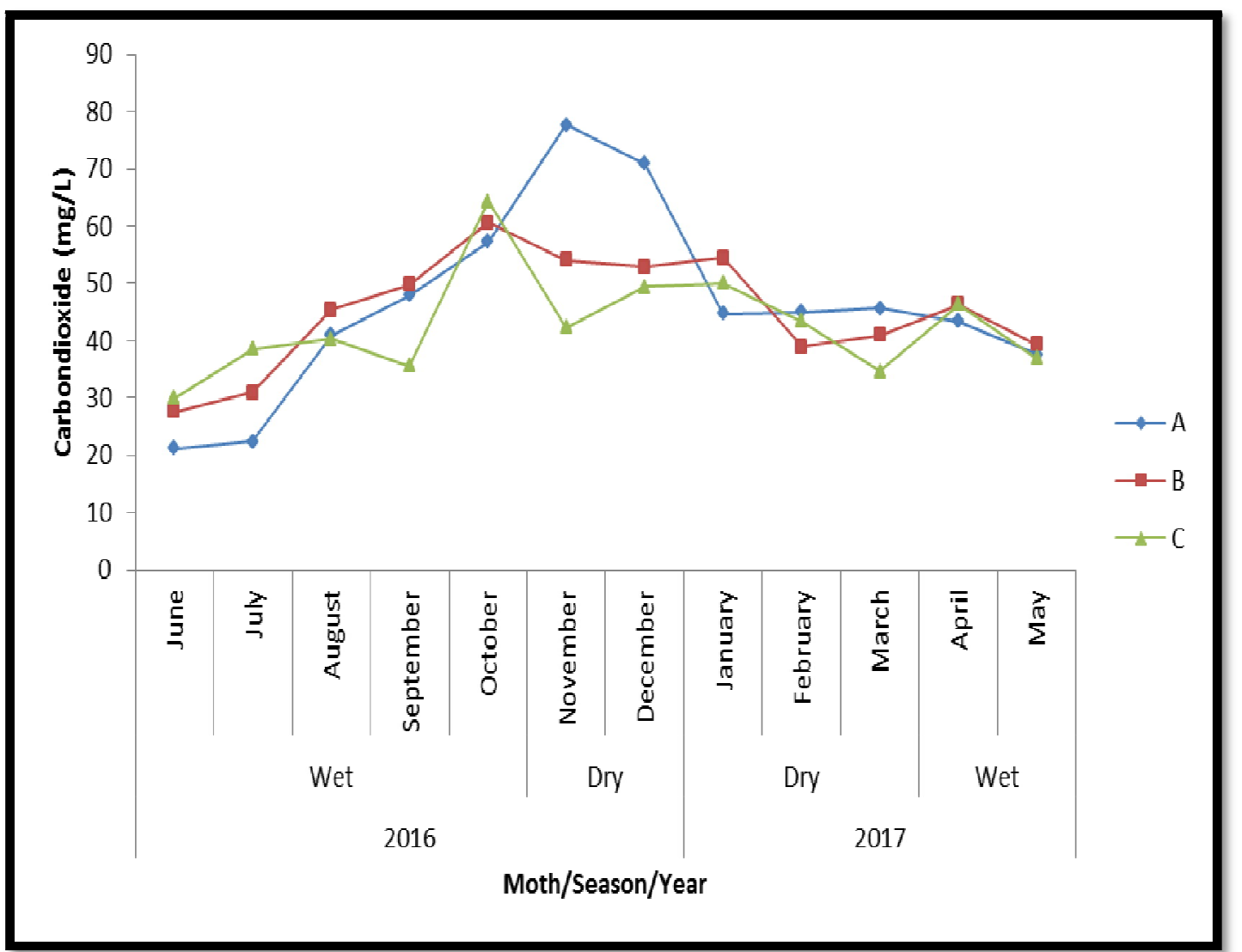

Figure 9: Monthly Variation in Carbon Dioxide Level of River Ochekwu 


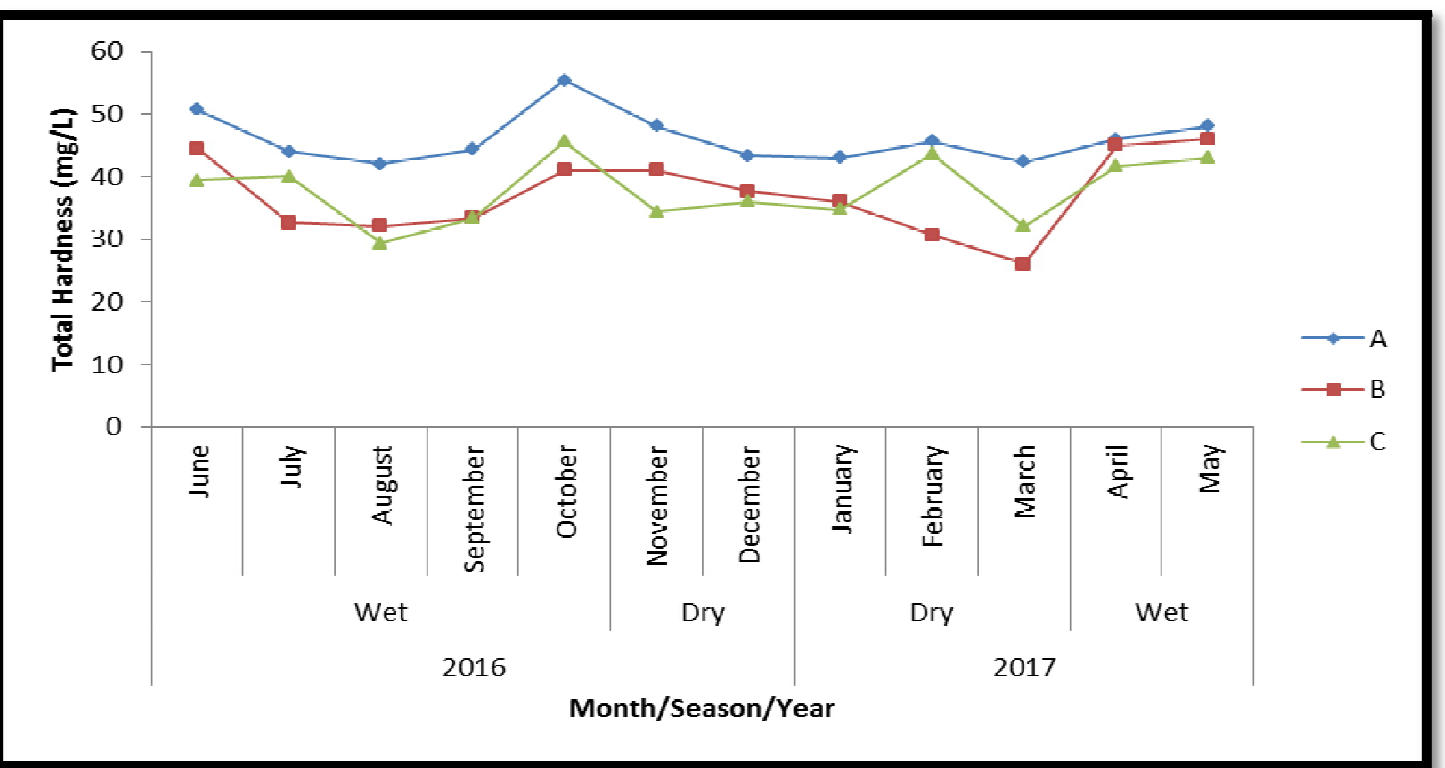

Figure 10: Monthly Variation in Total Hardness Level of River Ochekwu

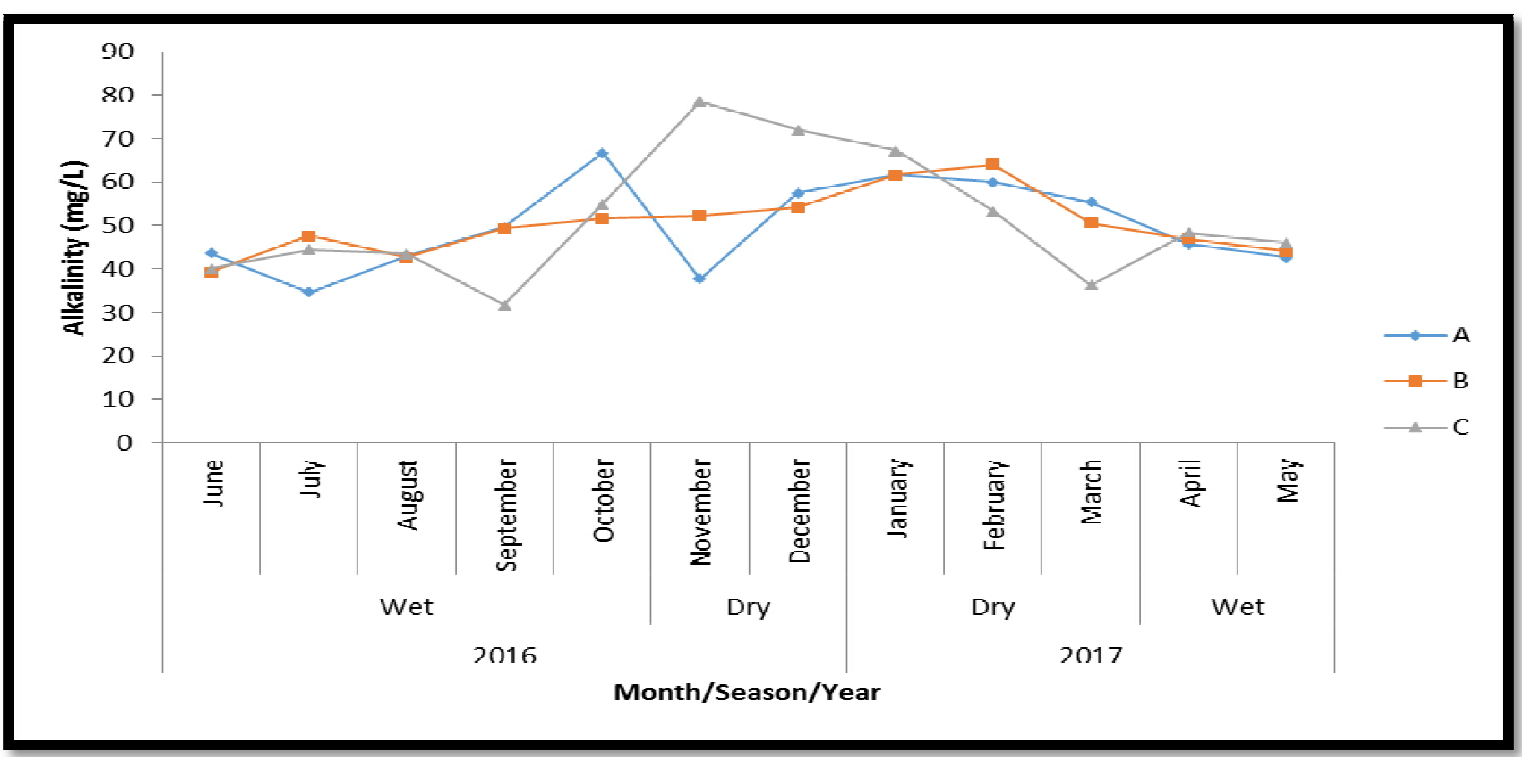

Figure 11: Monthly Variation in Alkalinity Level of River Ochekwu

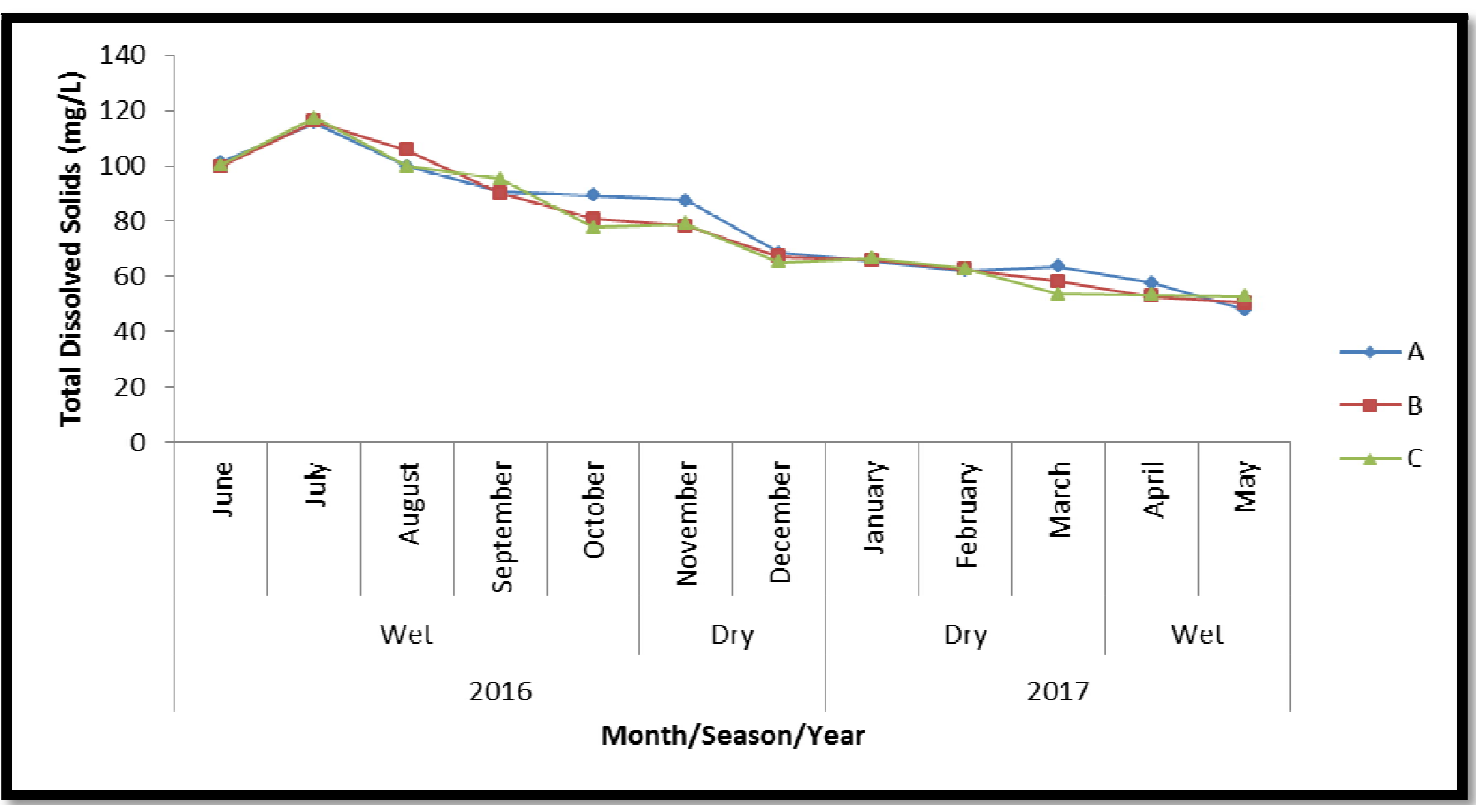

Figure 12: Monthly Variation in Total Dissolved Solids Level of River Ochekwu 


\subsection{Water Quality Parameters of River Ochekwu}

\subsubsection{Variation of Physico-Chemical Parameters by Station of River Ochekwu}

The result from the ANOVA showed that all the physical and chemical properties were generally within the limits for the survival and development of plankton and fish population. Table 1 showed that only the value for all the water parameters were not significantly different $(\mathrm{p}<0.05)$ across the three stations sampled. Total hardness however differs significantly from one station to the other ranging between $37.14 \pm 1.16 \mathrm{mg} / \mathrm{l}$ to $46.0 .5 \pm 0.84 \mathrm{mg} / \mathrm{l}$

\begin{tabular}{|c|c|c|c|c|}
\hline \multirow{2}{*}{ Water Quality Parameters } & \multicolumn{3}{|c|}{ Stations } & \multirow{2}{*}{ P-Value } \\
\cline { 2 - 4 } & $\mathbf{A}$ & $\mathbf{B}$ & $\mathbf{C}$ & \\
\hline Air Temperature $\left({ }^{\circ} \mathrm{C}\right)$ & $29.51 \pm 0.44$ & $29.98 \pm 0.48$ & $29.23 \pm 0.53$ & $0.55^{\text {ns }}$ \\
\hline Water Temperature $\left({ }^{\circ} \mathrm{C}\right)$ & $26.57 \pm 0.37$ & $26.66 \pm 0.29$ & $26.66 \pm 0.29$ & $0.95^{\text {ns }}$ \\
\hline Dissolved Oxygen $(\mathrm{mg} / \mathrm{L})$ & $4.91 \pm 0.15$ & $5.98 \pm 1.27$ & $4.59 \pm 0.11$ & $0.38^{\text {ns }}$ \\
\hline Biological Oxygen Demand $(\mathrm{mg} / \mathrm{L})$ & $2.95 \pm 0.08$ & $2.76 \pm 0.09$ & $3.80 \pm 0.81$ & $0.26^{\text {ns }}$ \\
\hline$p H$ & $6.79 \pm 0.15$ & $7.08 \pm 0.10$ & $6.89 \pm 0.07$ & $0.21^{\text {ns }}$ \\
\hline Transparency $(\mathrm{cm})$ & $43.36 \pm 1.96$ & $44.72 \pm 1.75$ & $42.99 \pm 1.87$ & $0.78^{\text {ns }}$ \\
\hline Total Dissolved Solids $(\mathrm{mg} / \mathrm{L})$ & $79.20 \pm 3.42$ & $77.43 \pm 3.53$ & $77.06 \pm 3.66$ & $0.90^{\text {ns }}$ \\
\hline Electrical conductivity & $83.56 \pm 6.02$ & $80.89 \pm 6.59$ & $80.25 \pm 6.26$ & $0.92^{\text {ns }}$ \\
\hline Carbon dioxide $(m g / L)$ & $46.24 \pm 2.74$ & $45.10 \pm 1.96$ & $42.65 \pm 1.73$ & $0.49^{\text {ns }}$ \\
\hline Alkalinity $(\mathrm{mg} / \mathrm{L})$ & $49.87 \pm 2.16$ & $50.37 \pm 1.49$ & $51.40 \pm 2.48$ & $0.86^{\text {ns }}$ \\
\hline Total Hardness $(\mathrm{mg} / \mathrm{L})$ & $46.05 \pm 0.84^{\mathrm{a}}$ & $37.14 \pm 1.16^{\mathrm{b}}$ & $37.75 \pm 1.33^{\mathrm{b}}$ & $<0.01$ \\
\hline
\end{tabular}

Table 1: Variations in Water Quality Parameters from Different Sampling Stations from River Ochekwu Means on the Same Row with Different Superscript are statistically Significant $(P<0.05)$

\subsubsection{Seasonal Variation of Water Quality Parameters of River Ochekwu}

Table 2 shows that only values of air temperature and $\mathrm{pH}$ were not significantly different $(\mathrm{p}>0.05)$ between wet and dry seasons. The table also shows that significant seasonal variation $(\mathrm{p}<0.05)$ exist among water temperature, $\mathrm{DO}$, BOD, TDS, CO2, Alkalinity, Transparency, and Total hardness with highest mean value of water temperature, DO, BOD, TDS, and total hardness occurring during the wet season and the lowest value occurring in the dry season. However, the highest value for air temperature, $\mathrm{pH}, \mathrm{CO}$, transparency and alkalinity were obtained in the dry season with the lowest value occurring in wet season.

\begin{tabular}{|c|c|c|c|c|c|}
\hline \multirow{2}{*}{ Water Quality Parameters } & \multicolumn{2}{|c|}{ Season } & df & T-Value & P-Value \\
\cline { 2 - 3 } & Dry & Wet & & & \\
\hline Air Temperature $\left({ }^{\circ} \mathrm{C}\right)$ & $29.78 \pm 0.57$ & $29.43 \pm 0.25$ & 61 & 0.56 & 0.57 \\
\hline Water Temperature $\left({ }^{\circ} \mathrm{C}\right)$ & $27.39 \pm 0.17$ & $25.62 \pm 0.35$ & 63 & 4.53 & $\varangle 0.01^{*}$ \\
\hline Dissolved Oxygen $(\mathrm{mg} / \mathrm{L})$ & $4.14 \pm 0.06$ & $5.89 \pm 0.72$ & 62 & 2.42 & $0.01^{*}$ \\
\hline Biological Oxygen Demand $(\mathrm{mg} / \mathrm{L})$ & $2.89 \pm 0.08$ & $3.37 \pm 0.47$ & 65 & 1.00 & 0.32 \\
\hline $\mathrm{pH}$ & $7.15 \pm 0.08$ & $6.76 \pm 0.09$ & 105 & 3.05 & $<0.01^{*}$ \\
\hline Transparency (cm) & $50.74 \pm 1.20$ & $38.70 \pm 1.30$ & 105 & 6.93 & $<0.01^{*}$ \\
\hline Total Dissolved Solids (mg/ L) & $67.20 \pm 1.40$ & $85.50 \pm 3.00$ & 85 & 5.57 & $<0.01^{*}$ \\
\hline Electrical Conductivity (mg/ L) & $52.80 \pm 1.70$ & $102.10 \pm 4.50$ & 77 & 10.16 & $\varangle 0.01^{*}$ \\
\hline Carbon dioxide $(\mathrm{mg} / \mathrm{L})$ & $49.70 \pm 2.00$ & $41.10 \pm 1.50$ & 87 & 3.46 & $\varangle 0.01^{*}$ \\
\hline Alkalinity $(\mathrm{mg} / \mathrm{L})$ & $57.50 \pm 2.00$ & $45.57 \pm 1.10$ & 72 & 5.26 & $<0.01^{*}$ \\
\hline Total Hardness(mg/ l) & $38.29 \pm 1.20$ & $41.76 \pm 0.96$ & 93 & 2.30 & $0.02^{*}$ \\
\hline
\end{tabular}

Table 2: Seasonal Variation of Water Quality Parameters of River Ochekwu

*Indicates Statistical Difference at $0.05 \%$

\subsubsection{Phytoplankton Variation across the Three Sample Stations along River Ochekwu}

Table 7 shows the different of phytoplanktons across the three sample stations along River Ochekwu. Thirty-five major species of phytoplankton from four families were identified. Chlorophyceae (green algae) was represented by 18 colonial, filamentous and unicellular forms which was the largest number of species in any given families. Chrysophyceae were represented by 4 species with no significant difference across the stations. Cyanophyceae (blue green algae) and Bacillariophyceae (Diatom) had 7 and 6 species respectively. There was no significant difference among the species across the stations. 


\begin{tabular}{|c|c|c|c|c|}
\hline \multirow[t]{2}{*}{ Phytoplanktons } & \multicolumn{3}{|c|}{ Stations } & \multirow[t]{2}{*}{ P-Value } \\
\hline & A & B & $\mathrm{C}$ & \\
\hline \multicolumn{5}{|l|}{ Chlorophyceae (Green algae) } \\
\hline Spirogyra insignis & $7.08 \pm 1.71$ & $6.92 \pm 1.34$ & $7.67 \pm 1.29$ & $0.93 \mathrm{~ns}$ \\
\hline Spirogyra communis & $4.92 \pm 1.26$ & $6.17 \pm 1.06$ & $6.25 \pm 1.01$ & $0.64^{\mathrm{ns}}$ \\
\hline Chlorella ellipsoidea & $7.50 \pm 0.92$ & $9.50 \pm 1.10$ & $6.50 \pm 1.03$ & $0.12^{\mathrm{ns}}$ \\
\hline Aphanocapsa elachista & $5.08 \pm 0.63^{a}$ & $5.33 \pm 0.71^{a}$ & $2.91 \pm 0.54^{b}$ & $0.02^{\mathrm{ns}}$ \\
\hline Scenedemus quaricauda & $2.75 \pm 0.69$ & $2.83 \pm 0.70$ & $2.25 \pm 0.52$ & $0.79^{n s}$ \\
\hline Scenedemus bijuga & $5.33 \pm 0.33$ & $5.66 \pm 0.59$ & $4.91 \pm 0.31$ & $0.47 \mathrm{~ns}$ \\
\hline Straurastrum cornuta & $3.16 \pm 0.42$ & $3.58 \pm 0.54$ & $2.75 \pm 0.62$ & $0.55^{\mathrm{ns}}$ \\
\hline Centronella reichelti & $6.83 \pm 0.68$ & $6.41 \pm 0.71$ & $4.75 \pm 0.74$ & $0.10^{\mathrm{ns}}$ \\
\hline Pediastrum simplex & $3.91 \pm 0.39$ & $4.50 \pm 0.55$ & $3.25 \pm 0.53$ & $0.22^{\mathrm{ns}}$ \\
\hline Straurastrum rotula & $6.75 \pm 0.30$ & $8.33 \pm 0.31$ & $6.33 \pm 0.28$ & $0.60^{\mathrm{ns}}$ \\
\hline Athrospira platensis & $5.83 \pm 0.45$ & $6.58 \pm 0.35$ & $5.33 \pm 0.55$ & $0.17 \mathrm{~ns}$ \\
\hline Closterium kuetzingii & $4.00 \pm 0.34$ & $3.58 \pm 0.52$ & $3.58 \pm 0.37$ & $0.72^{\mathrm{ns}}$ \\
\hline Hormidium rivulare & $5.83 \pm 0.49$ & $7.00 \pm 0.55$ & $5.91 \pm 0.54$ & $0.23^{\mathrm{ns}}$ \\
\hline Hydrodictyon reticulatum & $4.25 \pm 0.55^{b}$ & $6.41 \pm 0.48^{a}$ & $5.08 \pm 0.69 \mathrm{ab}$ & 0.04 \\
\hline Ulothrix tenissima & $4.16 \pm 0.61$ & $4.50 \pm 0.58$ & $3.33 \pm 0.82$ & $0.47 \mathrm{~ns}$ \\
\hline Synedra spp & $3.50 \pm 0.33$ & $4.33 \pm 0.33$ & $2.91 \pm 0.54$ & $0.08^{\mathrm{ns}}$ \\
\hline Volvox barberi & $4.00 \pm 0.42^{b}$ & $4.91 \pm 0.46^{\mathrm{ab}}$ & $5.75 \pm 0.56^{\mathrm{a}}$ & 0.04 \\
\hline Oedoganium grande & $0.58 \pm 0.22$ & $0.91 \pm 0.37$ & $0.16 \pm 0.11$ & $0.14^{\mathrm{ns}}$ \\
\hline \multicolumn{5}{|l|}{ Chrysophyceae } \\
\hline Synura spp & $2.58 \pm 0.35$ & $2.75 \pm 0.41$ & $1.58 \pm 0.33$ & $0.06^{\mathrm{ns}}$ \\
\hline Navicula digitoradiata & $2.58 \pm 0.35$ & $3.16 \pm 0.45$ & $1.66 \pm 0.49$ & $0.06^{\mathrm{ns}}$ \\
\hline Melosira granulata & $2.41 \pm 0.28$ & $2.83 \pm 0.58$ & $2.25 \pm 0.35$ & $0.61^{\mathrm{ns}}$ \\
\hline Fragillaria spp & $2.25 \pm 0.32$ & $1.91 \pm 0.35$ & $1.83 \pm 0.36$ & $0.67^{\mathrm{ns}}$ \\
\hline \multicolumn{5}{|l|}{ Cyanophyceae (Blue green algae) } \\
\hline Merismpedia spp & $1.75 \pm 0.32$ & $1.83 \pm 0.32$ & $2.00 \pm 0.36$ & $0.89^{\mathrm{ns}}$ \\
\hline Polycystis spp & $1.16 \pm 0.38$ & $1.25 \pm 0.50$ & $0.83 \pm 0.38$ & $0.77 \mathrm{~ns}$ \\
\hline Nostoc spp & $1.50 \pm 051$ & $1.33 \pm 0.58$ & $0.91 \pm 0.48$ & $0.72^{\mathrm{ns}}$ \\
\hline Anabaena spiroides & $1.83 \pm 0.36$ & $2.58 \pm 0.54$ & $2.00 \pm 0.42$ & $0.47 \mathrm{~ns}$ \\
\hline Spirulina major & $1.58 \pm 0.49$ & $1.91 \pm 0.63$ & $2.08 \pm 0.72$ & $0.84^{\mathrm{ns}}$ \\
\hline Oscillatoria ornata & $1.08 \pm 0.39$ & $1.00 \pm 0.36$ & $0.75 \pm 0.30$ & $0.79^{n s}$ \\
\hline Coelosphaerium spp & $2.08 \pm 0.31$ & $2.25 \pm 0.39$ & $1.75 \pm 0.42$ & $0.64^{\mathrm{ns}}$ \\
\hline \multicolumn{5}{|l|}{ Bacillariophyceae (Diatoms) } \\
\hline Navicula spp & $0.83 \pm 0.40$ & $1.00 \pm 0.53$ & $0.58 \pm 0.31$ & $0.78^{\mathrm{ns}}$ \\
\hline Synedra spp & $1.00 \pm 0.32$ & $1.00 \pm 0.42$ & $0.91 \pm 0.39$ & $0.98^{\mathrm{ns}}$ \\
\hline Aulacoseira spp & $1.08 \pm 0.28$ & $2.08 \pm 0.63$ & $2.16 \pm 0.57$ & $0.27 \mathrm{~ns}$ \\
\hline Cyclotella spp & $1.66 \pm 0.44$ & $1.66 \pm 0.52$ & $2.66 \pm 0.56$ & $0.30^{\mathrm{ns}}$ \\
\hline Coscinodiscus.spp & $1.33 \pm 0.43$ & $0.91 \pm 0.33$ & $1.00 \pm 0.30$ & $0.69^{n s}$ \\
\hline Melosira spp & $1.66 \pm 0.33$ & $1.75 \pm 0.49$ & $1.25 \pm 0.35$ & $0.64^{\mathrm{ns}}$ \\
\hline
\end{tabular}

Table 3: Variations of Phytoplanktons by Stations in the Different Stations in River Ochekwu Phytoplanktons Stations P-Value

Means on the Same Row with Different Superscript are statistically Significant $(\mathrm{P} \varangle 0.05)$; Ns = Not Significant

\subsubsection{Percentage Occurrence of Phytoplankton in River Ochekwu}

Figure 13 below shows the percentage occurrence of phytoplankton by stations within the period of study. Chlorophyceae had the highest percentage occurrence in stations A and B with Chrysophyceae having the least occurrence from both stations. In station $\mathrm{C}$, Chrysophyceae had the highest occurrence while Chlorophyceae recorded the least percentage occurrence level. 


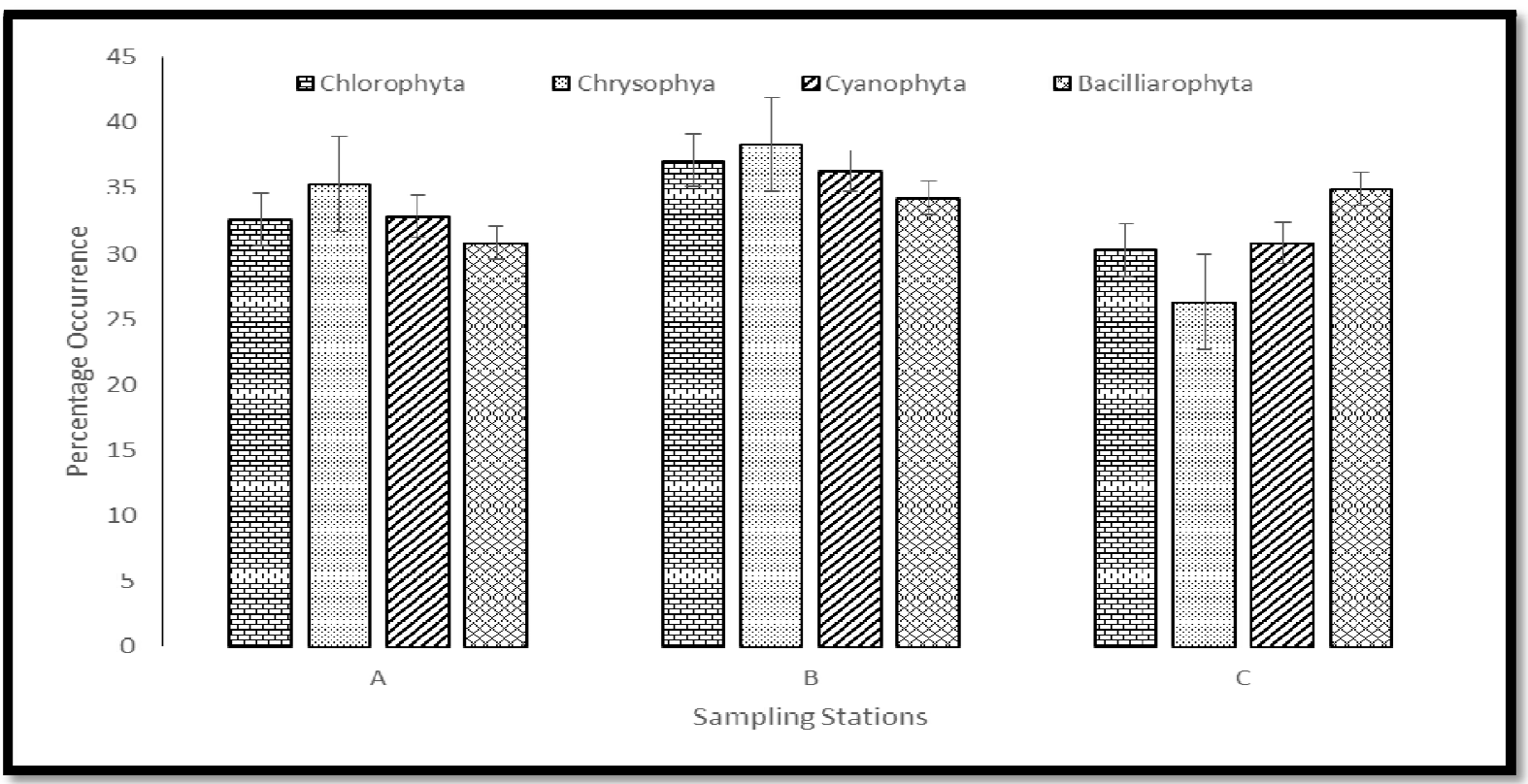

Figure 13: Percentage Occurrence of Phytoplanktons by Station from River Ochekwu

3.2.5. Variation of Zooplankton across the Sampled Stations in River Ochekwu

The result of variation of zooplankton across the three stations is shown in Table 9 below. Twenty-six major species of zooplankton from three families were identified during the study. Rotifera 12 species, Cladocera, 6 species and Copepoda, 5 species. Apart from Ptygra melicenta and Daphnia longispina, all other species were not significantly different across the sampling stations.

\begin{tabular}{|c|c|c|c|c|}
\hline \multirow[t]{2}{*}{ Zooplanktons } & \multicolumn{3}{|c|}{ Stations } & \multirow[t]{2}{*}{ P-Value } \\
\hline & A & $\mathrm{B}$ & $\mathrm{C}$ & \\
\hline \multicolumn{5}{|l|}{ Rotifers } \\
\hline Trichocerca cylindrica & $1.50 \pm 0.50$ & $1.91 \pm 0.65$ & $1.91 \pm 0.75$ & $0.87 \mathrm{~ns}$ \\
\hline Trichocerca elongata & $2.08 \pm 0.52$ & $2.50 \pm 0.69$ & $1.75 \pm 0.60$ & $0.68^{\mathrm{ns}}$ \\
\hline Brachionus angularis & $2.83 \pm 0.81$ & $4.00 \pm 1.11$ & $3.50 \pm 0.69$ & $0.65^{\mathrm{ns}}$ \\
\hline Brachionus falcatus & $3.33 \pm 0.72$ & $3.50 \pm 0.85$ & $3.83 \pm 0.94$ & $0.91^{\mathrm{ns}}$ \\
\hline Brachionus calyciforus & $3.91 \pm 0.41$ & $3.58 \pm 0.76$ & $3.50 \pm 0.57$ & $0.87^{\mathrm{ns}}$ \\
\hline Keratella cochlearis & $1.91 \pm 0.54$ & $2.83 \pm 0.68$ & $2.33 \pm 0.59$ & $0.57 \mathrm{~ns}$ \\
\hline Keratella tropica & $2.00 \pm 0.38$ & $2.41 \pm 0.51$ & $2.41 \pm 0.26$ & $0.78^{\mathrm{ns}}$ \\
\hline Filinia opoliensis & $0.75 \pm 0.37$ & $1.50 \pm 0.63$ & $0.41 \pm 0.26$ & $0.23^{\mathrm{ns}}$ \\
\hline Lecane decipiens & $0.75 \pm 0.30$ & $1.16 \pm 0.52$ & $0.50 \pm 0.33$ & $0.49^{\mathrm{ns}}$ \\
\hline Asplanchna spp & $1.66 \pm 0.35$ & $2.14 \pm 0.52$ & $1.66 \pm 0.44$ & $0.40^{\mathrm{ns}}$ \\
\hline Notholca spp & $0.66 \pm 0.33$ & $0.75 \pm 0.35$ & $0.66 \pm 0.41$ & $0.98^{\mathrm{ns}}$ \\
\hline Polyarthra delicoptera & $0.50 \pm 0.28$ & $0.91 \pm 0.35$ & $0.66 \pm 0.25$ & $0.62^{\mathrm{ns}}$ \\
\hline Polyarthra vulgaris & $0.58 \pm 0.28$ & $1.33 \pm 0.49$ & $0.58 \pm 0.26$ & $0.25^{\mathrm{ns}}$ \\
\hline Colurella spp & $0.33 \pm 0.14$ & $0.50 \pm 0.28$ & $0.41 \pm 0.19$ & $0.86^{\mathrm{ns}}$ \\
\hline Ptygra melicenta & $0.16 \pm 0.11^{b}$ & $0.75 \pm 0.30^{a}$ & $0.08 \pm 0.08^{b}$ & 0.04 \\
\hline \multicolumn{5}{|l|}{ CLADOCERANS } \\
\hline Daphnia longispina & $3.00 \pm 0.52^{\mathrm{ab}}$ & $4.50 \pm 0.52^{\mathrm{a}}$ & $2.50 \pm 0.54^{b}$ & 0.03 \\
\hline Ceriodapnia cornuta & $1.75 \pm 0.44$ & $2.41 \pm 0.58$ & $2.25 \pm 0.69$ & $0.70^{\mathrm{ns}}$ \\
\hline Bosmina longirostris & $1.41 \pm 0.43$ & $1.08 \pm 0.37$ & $1.33 \pm 0.51$ & $0.86^{\mathrm{ns}}$ \\
\hline Diaphanosoma exisum & $1.41 \pm 0.35$ & $2.00 \pm 0.70$ & $2.16 \pm 0.54$ & $0.61^{\mathrm{ns}}$ \\
\hline Mooina micrura & $3.08 \pm 0.54$ & $3.66 \pm 0.73$ & $2.58 \pm 0.78$ & $0.54^{\mathrm{ns}}$ \\
\hline Nauplius spp & $1.50 \pm 0.33$ & $2.25 \pm 0.56$ & $0.91 \pm 0.39$ & $0.12^{\mathrm{ns}}$ \\
\hline \multicolumn{5}{|l|}{ COPEPODA } \\
\hline Calanoid spp & $1.33 \pm 0.25$ & $1.91 \pm 0.51$ & $0.83 \pm 0.32$ & $0.14^{\mathrm{ns}}$ \\
\hline Copepodites spp & $1.25 \pm 0.47$ & $2.58 \pm 0.55$ & $1.75 \pm 0.64$ & $0.25^{\mathrm{ns}}$ \\
\hline Cyclopoid spp & $1.00 \pm 0.38$ & $1.58 \pm 0.69$ & $0.83 \pm 0.38$ & $0.55^{\mathrm{ns}}$ \\
\hline Limnocalans spp & $1.75 \pm 0.46$ & $1.75 \pm 0.64$ & $0.833 \pm 0.36$ & $0.34^{\mathrm{ns}}$ \\
\hline Diaptomus spp & $2.58 \pm 0.72$ & $2.00 \pm 0.50$ & $1.66 \pm 0.46$ & $0.53^{\text {ns }}$ \\
\hline
\end{tabular}

Table 4: Variations in Zooplanktons by Stations of River Ochekwu

Means on the Same Row with Different Superscript are statistically Significant $(\mathrm{P} \varangle 0.05)$ 


\subsubsection{Percentage Occurrence of Zooplankton from River Ochekwu}

Figure 14 below shows the percentage occurrence of Cladocera, Rotifera and Copepoda in the three sampled stations. Cladocera had the highest percentage occurrence in both stations A and B while Rotifera had the highest percentage occurrence in station $\mathrm{C}$ with Cladoceran recording the least.

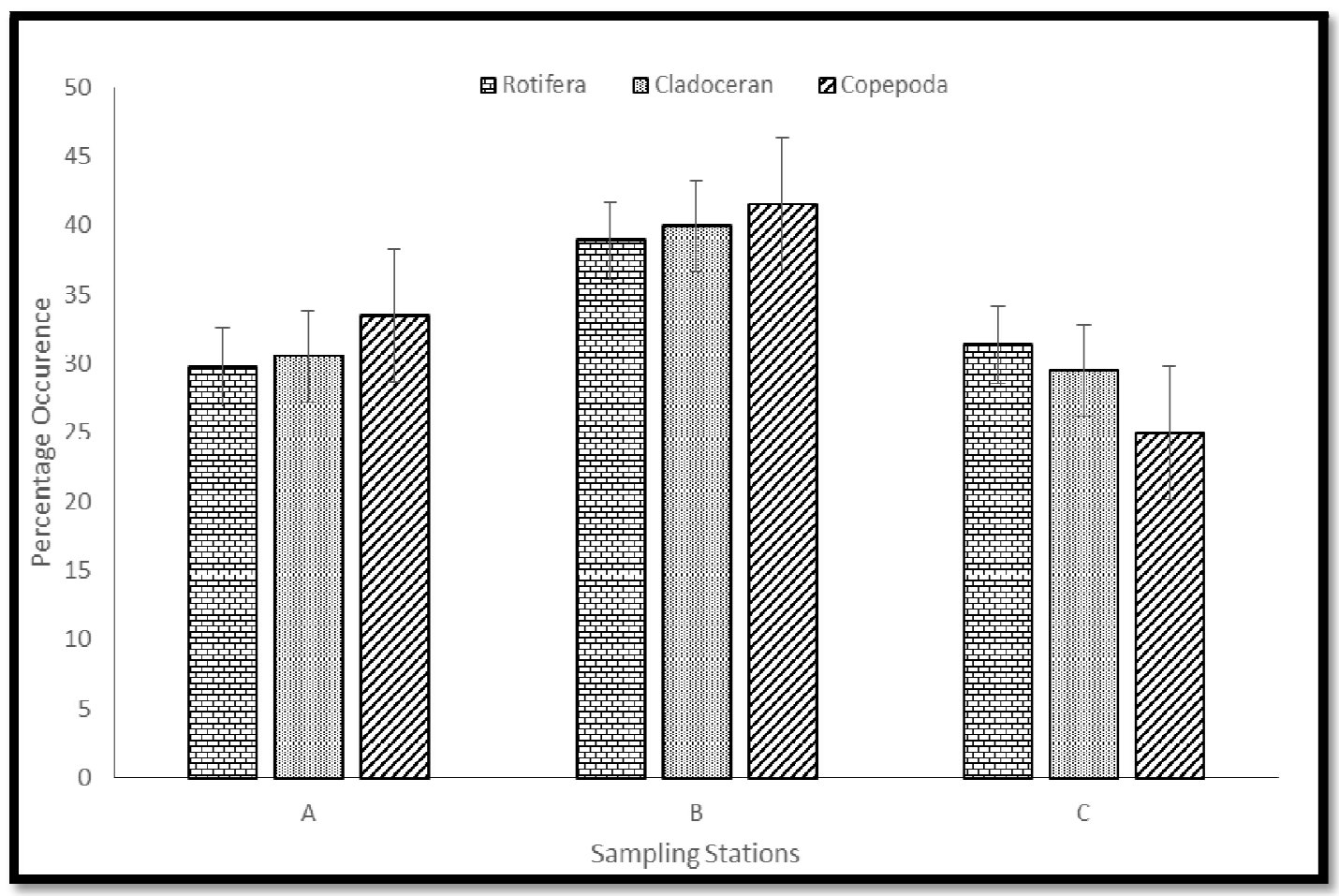

Figure 14: Percentage Occurrence of Zooplanktons by Station from River Ochekwu

\section{Discussion}

Surface water temperature is an indispensible ecological factor that regulates the physiological behavior and distribution of aquatic organisms. Lower temperature is reported to likely reduce metabolism and growth (Abowei, 2010). The present study recorded a mean surface water temperature of $25.55 \pm 0.59$ and $27.30 \pm 0.42$ in dry and wet seasons respectively. This result agrees with the observation in River Andoni where the mean surface was 25-30 (Komi, 2013). Okayi et al., (2011) reported surface water temperature off 20.00-23.10 in River Benue, which is in disagreement with the result of this study. This may be due to the fact that larger water bodies tend to respond much slower to temperature changes than smaller rivers.

The mean Electrical Conductivity obtained from this study was $55.10 \pm 2.70$ in dry season and $103.90 \pm 7.50$ in wet season. This result is below the maximum permissible limit of $1000.00 \mu \mathrm{s} / \mathrm{cm}$ specified by WHO and Nigerian standard for drinking water quality (WHO 2004, NSDW 2007). The mean conductivity result obtained in this study is similar to that of Eneji et al., (2012) who reported mean conductivity value of $86.85 \pm 2.43 \mu \mathrm{s} / \mathrm{cm}$.

The mean potential hydrogen $(\mathrm{pH})$ value of $7.04 \pm 0.17$ observed in dry season and $6.62 \pm 0.23$ in wet season falls within the recommended range of $6.5-8.5$ by WHO and National standard for drinking water quality in Nigeria (WHO 2004, NSDWQ 2007). Previous studies in River Benue reported the mean pH range of 5.9-6.8 (Okayi et al., 2011). Similarly, Eneji et al., (2012) reported the mean $\mathrm{pH}$ value of $7.01 \pm 0.03$ for River Benue at Makurdi. Higher $\mathrm{pH}$ value is an indicator of pollutant intrusion. The result of this study disagrees with Abowei (2010) who reported a pH range of 7.3-7.6 in Nkoro River, Niger Delta, Nigeria.

The total dissolved solids (TDS) in water consist of inorganic salts and dissolved materials. High values of TDS may lead to change in taste of water and deteriorate plumbing appliances. The mean value of TDS of this work falls within the WHO recommendation value of $1000.00 \mathrm{mg} / \mathrm{l}$ and $500.00 \mathrm{mg} / \mathrm{l}$ of the National standard of drinking water quality (WHO 2009, NSDWQ 2005). The TDS value obtained during the course of this work is suitable for aquaculture and growth in River Ochekwu (WHO 2004).

During the course of this study, DO value range is not similar with the result of an earlier study by Eneji et al., 2012, where lower mean value of DO $(1.80 \pm 0.06)$ was reported in River Benue. However, this study is in agreement with the study carried out by Elaigwe et al., (2004) who reported DO value of the range of 4.0- 7.0mg/ l of River Mu, Benue state. The high DO concentration in the wet season may be due to aeration of surface water by wave action and photosynthetic activities of phytoplankton and aquatic macrophyte. However, the result of this study disagrees with the findings of higher values of DO in the dry months compared to the wet months (Adefemi et al., 2007, Eneji et al., 2012).

Biochemical Oxygen Demand (BOD) is not a specific pollutant but rather a measure of the amount of oxygen required by bacteria and other microorganisms engaged in stabilizing decomposable organic matter. BOD tends to increase as biodegradable organic matter increases. Usually, BOD increases where there is a decrease in DO (Narayanan, 2007). The European environmental agency (1994) compiled monitoring results from European rivers and found average BOD levels far near pristine rivers of about $1.6 \mathrm{mg} / \mathrm{l}$. The agency concluded that rivers that are slightly affected by human activities 
generally have a BOD value below $2.00 \mathrm{mg} / \mathrm{l}$ whereas a BOD exceeding $5.00 \mathrm{mg} / \mathrm{l}$ generally indicates pollution. Degradation of organic matter by heterotrophic bacteria is one of the major processes controlling the oxygen level of aquatic ecosystem and thus their quality. In this study, a mean BOD value of $2.84 \pm 0.08$ to $3.10 \pm 0.16$ was obtained. This result disagrees with the result of an earlier study in River Benue at Makurdi that reported a mean BOD of $8.23 \pm 0.40 \mathrm{mg} / \mathrm{l}$ (Eneji et al., 2012). Nevertheless, the result of this study conforms to that of Elaigwu et al., (2004) who reported BOD in the range of 1.0 to $3.9 \mathrm{mg} / \mathrm{l}$ in River mu Benue State. The low mean value of BOD obtained in this study may be attributed to the level of DO and may be as a result of low oxygen consuming waste in River Ochekwu. BOD is a measure of oxygen use or oxygen potential use. High BOD value may be harmful to the biological community in the aquatic system if the oxygen consumption is great enough to cause anaerobic conditions. This result is often reflected in the disruption of ecological process (Longe and Omole, 2008).

Secchi disc transparency was high during the dry season $(53.05 \pm 1.30)$ and low during the rains $(36.40 \pm 2.20)$ and flood periods. The lower transparency observed during the rains and flood could be due to high water run-off from the water shed into the river. This wash silts, sediments, debris, organic, inorganic and suspended particles into the water body. The light attenuation by these particles reduced the secchi disc visibility. Gliwicz (1999) had noted that increase turbidity is associated with raining season that bring in clay from the water shed or with windy season causing sediment suspension and bank erosion in shallow reservoirs. The decrease noticed in secchi disc transparency agrees with the findings of Imerbore and Adeniyi (1977). Higher transparency recorded during the dry season may be attributed to the settling of the water particles at the bottom of the river. The depth of transparency in the river lies in the pelagic region which had a rich and diverse species of planktons and fishes due to its exposure to sunlight and could be described as the most productive region of the river.

Higher carbon dioxide concentration during the dry season may be attributed to the high rate of decomposition of organic matter in the river and its low up take by phytoplankton, since phytoplankton density was low during the dry season. This time also corresponds to low dissolved oxygen production as compared to wet season. Renn (1968) noted that during low oxygen periods carbon dioxide is released in high levels. This scenario was reported in Pankshin Reservoir by Kemdirim (1987). The low concentration of carbon dioxide during the raining season could be due to its active uptake by phytoplankton density in the river. Combined effects of decomposition, higher respiration from biotic organisms and profuse diffusion from the atmosphere may explain the highly significant $(\mathrm{p}<0.01)$ concentration of carbon dioxide in the dry season. Large phytoplankton biomass which develops during the rains might have removed the carbon dioxide for their photosynthesis thus leading to low concentration of the nutrients during the rains.

The Total Alkalinity of River Ochekwu is a reflection of its carbonate and bicarbonate profile with likelihood of silicate and phosphate contributing to it. This is so because phenolphthalein alkalinity was absent in the river. Campbell and Wildberger (2001) reported that phenolphthalein alkalinity is usually low or absent in water dominated by bicarbonate ions. High value recorded during the dry season could be due to higher concentration of carbon dioxide and the release of bicarbonates ions by sediments and rocks (Wetzel, 2001). The lower value recorded during the raining season could be attributed to the low concentration of carbon dioxide dilution of water or the sediments taking up the carbonates ions. The total alkalinity value could have had an impact in the productivity of the river and might have aided fish production. It is believed that total alkalinity above $40 \mathrm{mg} / \mathrm{l}$ is indicative of high productivity (Sugunan, 1997). Alkalinity was a buffer for $\mathrm{pH}$ changes caused by photosynthesis thus helping to stabilize the $\mathrm{pH}$ in the river. The higher concentration of total alkalinity in station $\mathrm{C}$ could be due to the presence of carbonate and bicarbonates ions from anthropogenic activities.

The mean range of water hardness of River Ochekwu varies from $44.42 \pm 1.20$ to $47.19 \pm 1.10$. Is soft going by the hardness scale of Hanna (2003). The ions were probably derived from drainage of its underlying rock basins (Hutchinson 1957). The total hardness of this river could be due to the presence of calcium and magnesium ions. According to Boyd and lichtkoppler (1979), desirable range of total hardness for fish production falls within $20 \mathrm{mg} / \mathrm{l}$ to $300 \mathrm{mg} / \mathrm{l}$. The higher value of total hardness in the wet season could be due to high concentration of calcium and magnesium ions. The lower concentration seen in the dry season may be as a result of uptake of these ions by planktons and shelled animals.

The phytoplankton composition of River Ochekwu is very rich, abundant, diverse and heterogeneous. This may be due to the presence of high nutrients as well as the shallow nature of the river which greatly expose the surface to light for algal productivity. The 21 species of phytoplankton were abundant during the raining season. This scenario has been reported by Adeniji (1973) on kanji and Jebba lakes and Egborge (1974) on River Oshum while Thomas et al., (2000) observed that high primary productivity is usually rain-induced in tropical reservoirs. The dominance of class chlorophyceae (greenalgae) could be explained by the high concentration of nitrate and phosphate and may be responsible for the bloom of chlorophyceae and cyanophyceae.

The composition and abundance of phytoplankton is strongly influenced by the seasonal fluctuation in the physico-chemical and biological factors. The dominance of green algae is typical of tropical rivers and lakes (Wood and Talling 1900) and has been reported by Reynolds (1996). The absence of desmids could be due to their preference for brackish or high saline water as observed by Opute (2000). The significant higher total phytoplankton abundance in the wet season could be due to high amount of nutrients which came with rains and washed them down to the river. Amarinsinghe and Vijverbery (2002) reported that phytoplankton bloom occurred after the rains in a tropical reservoir in Sri Lanka. The lower number of total phytoplankton observed at this period could be a response to the low nutrient available.

The zooplankton community of River Ochekwu could be attributed to the presence of rich and diverse assemblage of phytoplankton on which they feed. This is evident from the decrease noticed in the phytoplankton population in the dry season. Also, the abundance of zooplankton was correlated with the upsurge of phytoplankton. This scenario has been 
pointed out by many researchers including Kemdirin (1987), Istanovics and Somlyody (1999). Unlike the phytoplankton, the zooplanktons are generally less diverse in average genera number. Khan and Ejike (1984) have also reported limited genera diversity and abundance of zooplankton in Jos plateau reservoir. The order of dominance of the zooplankton was Rotifera - Cladocerans - Copepoda. Rocha et al., (1999) observed that typical zooplankton assemblages of reservoirs are commonly constituted by Rotifera, Cladocerans and Copepoda, while Aimnu and Saidu (2001) also observed the three groups in Lake Chad. The distribution and abundance of zooplankton was determined by the amount of food (nutrients and phytoplankton) and predation (by fish). The dominance of Rotifera agrees with the findings of Akin-Oriola (2003) who reported dominance of Rotifera in Rivers. The relatively low abundance of cladocerance and copepods might be as a result of hydrodynamics of the river, such as water volume and residence time. The significant higher zooplankton in rainy season could be explained by the presence of significant amount of total phytoplankton in that season and low grazing by active predators. Sluscaczyk (1999) concludes that the absence of fish predation usually stimulates the development of large bodied Cladocerans.

\section{Conclusion}

The linmological assessment of River Ochekwu shows the surface water quality to be excellent which could be classified under class 1 of the Prat et al., (1971) index of water quality classification and using environmental quality standards (EQS) (WWI, 2007). Its ecological status could be said to be high while its chemical status could be described as pass. The determinants used in arriving at this classification such as dissolved oxygen, BOD, EC, TDS and pH were found in the range acceptable for drinking water (WHO 1997) and fish production, irrigation and recreation (Hach, 2003).

River Ochekwu can be considered as productive going by the qualitative and quantitative assessment of the primary productivity of the phytoplankton and zooplankton. This classification of the river is necessary to direct appropriate management that benefits the river in tackling the challenges posed by eutrophication, decimation and declining fish species.

This study highlighted the need for stakeholders to be on the watch for harmful practices which may be detrimental to the fish population. The dynamics of River Ochekwu shows seasonality in its hydrology, productivity and periodicity with high water volume, plankton productivity and fish diversity in the rainy season. Further understanding of this dynamic will allow the development of better ways of monitoring and managing the river and its fisheries of which the present study has provided a base line data that was nonexistent for the river prior to this study.

\section{References}

i. Abowei, J. F. N. (2010). Salinity, dissolved oxygen, pH and surface water temperature condition on Nkoro River, Niger Delta, Nigeria. Res. Journal of Environmental Earth Science. 2(1): 16-21.

ii. Adefemi, O. S., Asaolu, S.S. and Olaofe, O. (2007). Assessment of the physico-chemical status of water sample from major dams in Ekiti State, Nigeria. Pakistan Journal of Nutrition, Vol. 6, No. 6. Pp. 657-659. ISSN 1680-5194.

iii. Adefemi, S. O and Awokunmi, E.E. (2010). Determination of physico-chemical parameters and heavy metals in water samples from itaogbolu area of Ondo-State, Nigeria. African Journal of Environmental Science and Technology. Vol. 4 (3), pp. 145-148.

iv. Adeniji, H.A. (1991). Limnology and biological production in the pelagic zone of Jebba Lake, Nigeria Ph.D Thesis University of Ibadan, Ibadan Nigeria pp.278.

v. Akin-Oriola, G. A. (2003). Zooplankton association and environmental factors in Ogunpa and Ona Rivers, Nigeria, Rev. Biol. Trop 51(2): 391-398.

vi. Amarinsinghe, P. B. and Vijverberg, J. (2002). Primary production in a tropical reservoir in Sri lanka 487:85-93.

vii. Aminu, R and Ahmed, K. S. (2001). Plankton periodicity and some physicochemical parameters of the Take Channel of Lake Chad. Journal of Aquatic Science, 19(2): 104-110.

viii. Boyd, C. E. and Lichtkoppler, F. (1979). Water quality management in pond culture. Research and Development series No. 22 project AD/ Dsan - G003930p.

ix. Campbell, G and Wildberger, S. (2001). The monitor's hand book. A reference guide for Natural water Monitoring. Lamotte Company, Chester town, Marryland USA. Pp.63.

x. Ebigwui, J. K.Imedimfon, I. E, Bright, H. A, Olowu, C and Ekanem, F.A. (2014). Physico-chemical parameters and phytoplankton assemblage along spatial and temporal gradients in great Kwa River, Calabar, Nigeria. International Journal of Biological Chemistry. Vol. 8 (1): pp. 1-20.

xi. Egborge, A. B. M. (1974). The hydrobiology and plankton of Lake Asegine. Nigeria PhD Thesis,University of Ibadan. Nigeria.

xii. Ejike, C. (1984). Limnology and plankton periodicity of Jos Plateau Water Reservoir, Nigeria, West Africa.

xiii. Ekweozor, I.K.E and Moslen, M. (2016). Abundance and diversity of plankton of Ekerekana and Okochiri Creeks in the Upper Bonny Estuary, Nigeria. Nigerian Journal of Oil and Gas Technology.

xiv. Elaigwe, S. E. Ajibola, V. O and Olaramini, F. M. (2007). Studies on impact of municipal waste dump site surrounding soil and air quality of two northern cities in Nigeria. Journal of Applied Science. Vol. 7 (3): pp.421425.

xv. Eneji, J. S., Agada, P. O. and Sha Ato, R. (2012). Spatial and temporal variation in water quality of River Benue Nigeria. Journal of Environmental Protection. 3: 1-7.

xvi. Gliwicz, M. Z. (1999). Plankton Ecology: Succession in plankton communities. Pp. 253-296. 
xvii. Imevbore, A. M. A. and Adeniyi, F. (1977). Contribution on the role of suspended solids to the chemistry of Lake Kaniji, In: Interactions between sediments and fresh water edited by H. L. Golterman: The Hague, Dr. W. Junk, 6. V. publishers. 335-342.

xviii. Kemdirin, E. C. (1987). Advances in Virus Research. https:// books.google.com.ng>books.

xix. Komi, G. W. (2013). Mortality and Exploitation of Penaeus monodon in the Andoni River, Nigeria. Journal of Natural Science Research. Vol. 7 (15) pp. 58-67.

xx. Longe, E. O. and Omole, D. O. (2008). Analysis of pollution status of River, Illo, Ola, Nigeria.Environmentalist,28:451-457. http// dx.doi.org/ 10.1007/ S10669-008-9166-4.

xxi. Narayanan, P. (2007). Environmental pollution: principles Analysis and Control. CBS publishers and distributors PVT ltd New Delhi India p. 671.

xxii. Nigerian Standard for Drinking Water (NSDW) (2007). Nigeria industrial standard NIS 554, Standard Organization of Nigeria, Lagos. P. 30.

xxiii. Okayi, R. G., Chokom, A. A and Anyera, S. M. (2011). Aquatic macrophytes and water quality parameters of selected flood plains and River Benue, Makurdi, Benue State, Nigeria. Journal of Animal and Plant Science. 3(12): 16531662.

xxiv. Oluduro, A. O and Aderiye, B. I. (2007). The microflora or surface and underground water. Journal of Plant Science. Vol. 2 (4): pp. 453-458.

xxv. Oputa, F. I. (2000). Contribution to the Knowledge of algae of Nigeria. Desmids from warri/ Forcados estuaries. Journal limnology. 59(2): 131-155.

xxvi. Reynold, C.S. (2006). Ecology of phytoplankton. 1st Edition, Cambridge University Press. New York, p. 535.

xxvii. Rocha-Olivares, A.C.A, Eimbrell, B. J, Eitner and Vetter, R.D (1999). Evolution of a mitochondrial cytochrome b gene sequence in the species-rich genus sebastes (Teleostei, Scor-paenidae) and its utility in testing the monophyly of the sub genus sebastomus. Mol. Phylogenet, E Vol. 11 (3): pp 426-440.

xxviii. Slusarczyk, M. (1999). Impact of fish predation on small bodied Cladocerans: Limitation or stimulation? Hydrobiology 342/ 243: 315-221.

xxix. Taiwo, A. M., Adeogun, A. O. Olatunde, K. A. and Adegbite, K. I. (2012). Analysis of groundwater quality of hand-dug wells in peri-urban areas of Obantoko, Abeokuta, Nigeria for selected physico-chemical parameters. Pacific journal of science and Technology, Vol. 12, No. 1, (May 2011), pp. 527-534. www. Akamaiuniversity.us/ PJST12_1 527.pdf.

xxx. Thomas, D.D. Donnelly, C. A. Wood, R. J and Alphey, L. S. (2000). Inscet population control using a dominant, repressible, lethal genetic system. Journal of Natural Science Res

xxxi. Water and Waste Water international (WWI). (2007). Working to meet water framework directives. Vol. 22(2): 37-39.

xxxii. Wetzel, R. G. (2001). Limnology: Lake and River ecosystem, 3rd edition. Academic press. New York Pp 1006.

xxxiii. World Health Organization (WHO). (2004). Drinking water guidelines available at http:/ 103.whosea.org.tehifor/ water/ litm/ 103pp. 